\title{
$\beta$-Carotene-vitamin A equivalence in Chinese adults assessed by an isotope dilution technique
}

\author{
Zhixu Wang ${ }^{1,2 *}$, Shian Yin ${ }^{1}$, Xianfeng Zhao ${ }^{1}$, Robert M. Russell ${ }^{3}$ and Guangwen Tang ${ }^{3}$ \\ ${ }^{1}$ National Institute for Nutrition and Food Safety, Chinese Centre for Disease Control and Prevention, Room 202, \\ 29 Nanwei Road, Xuanwu District, Beijing, China 100050 \\ ${ }^{2}$ Institute of Medical Nutrition, Qingdao University Medical College, Qingdao, China 266021 \\ ${ }^{3}$ Jean Mayer US Department of Agriculture Human Nutrition Research Center on Aging at Tufts University, Boston, \\ MA, USA 02111
}

(Received 28 January 2003 - Revised 22 September 2003 - Accepted 24 September 2003)

\begin{abstract}
The present study was carried out to determine the conversion factor of synthetic ${ }^{2} \mathrm{H}$-labelled $\beta$-carotene to vitamin A in Chinese adults by using a stable-isotope dilution technique. Fifteen healthy volunteers aged 50-60 years were recruited for a $55 \mathrm{~d}$ experiment. The volunteers (nine males and six females) were each given a physiological dose of $\left[{ }^{2} \mathrm{H}_{8}\right] \beta$-carotene $(6 \mathrm{mg})$ in oil on the first day of the experiment, and a reference dose of $\left[{ }^{2} \mathrm{H}_{8}\right]$ retinyl acetate $(3 \mathrm{mg})$ in oil was given on the fourth day. Serum samples were collected at $0,3,5,7,9,11$, and $13 \mathrm{~h}$ on the first and the fourth days of the study, daily for $10 \mathrm{~d}$, and then weekly from days 14 to 56 . $\beta$-Carotene and retinol were extracted from serum and isolated by HPLC, and their enrichments were respectively determined by using GC-electron capture negative chemical ionisation-MS and LC-atmospheric pressure chemical ionisation interface-MS. Four of the subjects exhibited $\beta$-carotene to vitamin A conversion factors of $>29 \cdot 0: 1$ on a molar basis and were termed 'poor converters'. In the eleven normal converters (seven males and four females), the calculated conversion factors of $\beta$-carotene to retinol ranged from 2.0:1 to 12.2:1 with an average of 4.8 (SD 2.8):1 on a molar basis, and from 3.8:1 to 22.8:1 with an average of 9.1 (SD 5.3):1 on a weight basis. The $52 \mathrm{~d}$ post-intestinal absorption conversion was estimated to be about $30 \%$ of the total converted retinol.
\end{abstract}

ß-Carotene: Vitamin A: Biological conversion efficiency: Isotope dilution technique

Vitamin A is needed for vision, growth, reproduction, cellular differentiation and proliferation, and for the integrity of the immune system. Vitamin A deficiency can have serious health consequences such as blindness (Solomons, 2001), and increased mortality from infection (World Health Organization, 1995). Conversely, excessive intakes of vitamin A can result in teratogenicity (Rothman et al. 1995), liver damage and increased bone loss (Solomons, 2001). Dietary $\beta$-carotene is the main provitamin A carotene in food and does not result in vitamin A toxicity even when ingested at high doses. Although $\beta$-carotene has been considered as a safe vitamin A source (Food and Agriculture Organization/World Health Organization, 1967; Olson, 1986), its conversion efficiency to vitamin $\mathrm{A}$ in man is uncertain.

The retinol equivalence of dietary $\beta$-carotene has been defined classically as $6 \mu \mathrm{g} \beta$-carotene being equal to $1 \mu \mathrm{g}$ retinol (Food and Agriculture Organization/World Health Organization, 1967; National Research Council, 1989; Chinese Nutrition Society, 2000). In China, this 6:1 factor is still used (Chinese Nutrition Society, 2000), although a factor of 12:1 has recently been promulgated in the USA and Canada (US Institute of Medicine, 2001). The conversion efficiency of $\beta$-carotene to vitamin $\mathrm{A}$ is influenced by many factors and varies widely with dose and different physiological situations (RibayaMercado et al. 2000; Tang et al. 2000). The 6:1 factor of $\beta$-carotene to vitamin A was based on depletion-repletion studies (Goodman et al. 1966; Blomstrand \& Werner, 1967; Sauberlich et al. 1974), and reflects the conversion factor of $\beta$-carotene to vitamin $\mathrm{A}$ in vitamin A-depleted subjects. This factor would therefore probably not be applicable to a relatively well-nourished population.

The conversion of $\beta$-carotene to vitamin $A$ cannot be quantified in well-nourished human subjects by administering unlabelled $\beta$-carotene due to the inability to distinguish newly formed retinol from the body reserves, though the triacylglycerol-rich lipoprotein (TRL) model allows quantification with non-physiological doses. The conversion of $\beta$-carotene to vitamin $A$ was therefore investigated in well-nourished subjects by administering isotopically labelled $\beta$-carotene $\left(\left[{ }^{2} \mathrm{H}_{8}\right] \beta\right.$-carotene $)$ and $\left[{ }^{2} \mathrm{H}_{8}\right]$ retinyl

\footnotetext{
Abbreviations: APCI, atmospheric pressure chemical ionisation; AUC, area under the curve; ECNCI, electron capture negative chemical ionisation; HNRCA, Human Nutrition Research Center on Aging at Tufts University; RAc, retinyl acetate.

* Corresponding author: Dr Zhixu Wang, fax +86106301 1875, email zxwong@public.qd.sd.cn
} 
acetate (RAc) as the vitamin A reference (Tang et al. 1997, 1998, 2000, 2003). By this method, the newly administered labelled $\beta$-carotene and its metabolite, retinol, together with the labelled reference dose of retinol can be traced clearly at physiological dose levels.

\section{Materials, subjects and methods}

\section{Labelled compounds}

$\left[{ }^{2} \mathrm{H}_{8}\right] \beta$-carotene $\left(11,11^{\prime}, 19,19,19,19^{\prime}, 19^{\prime}, 19^{\prime}-{ }^{2} \mathrm{H}_{8^{-}}\right.$ labelled $\beta$-carotene, $82.0 \%$ in the all-trans form, $8.0 \%$ in the 13-cis form, $4.2 \%$ in the 9-cis form and $3.4 \%$ in the 15-cis form; BASF Products, Ludwigshafen, Germany), dissolved in maize oil and contained in gelatin capsules, was provided to the National Institute for Nutrition and Food Safety (Beijing, China) by the Jean Mayer US Department of Agriculture Human Nutrition Research Center on Aging at Tufts University (HNRCA), Boston, MA, USA. The crystalline $\left[{ }^{2} \mathrm{H}_{8}\right] \beta$-carotene dissolved in ethanol was checked by HPLC before it was dissolved in oil for experimental use, and the chemical purity spectroscopically of the labelled $\beta$-carotene was $90.6 \%$. It also contained $\left[{ }^{2} \mathrm{H}_{7}\right] \beta$-carotene $(15.7 \%), \quad\left[{ }^{2} \mathrm{H}_{6}\right] \beta$-carotene $(0.3 \%)$, and $\left[{ }^{1} \mathrm{H}\right] \beta$-carotene $(2.9 \%)$ as measured by atmospheric pressure chemical ionisation (APCI)-MS (Tang et al. 2003). The oral doses of $\left[{ }^{2} \mathrm{H}_{8}\right] \beta$-carotene were corrected by a purity factor of $90.6 \%$ in data processing.

$\left[{ }^{2} \mathrm{H}_{8}\right]$ RAc $\left(10,14,19,19,19,20,20,20-{ }^{2} \mathrm{H}_{8}\right.$-labelled RAc) (Cambridge Isotope Laboratory product, Andover, MA, USA) was also dissolved in maize oil and, contained in gelatin capsules, provided to the National Institute for Nutrition and Food Safety by the HNRCA. The purity of $\left[{ }^{2} \mathrm{H}_{8}\right]$ RAc was $>98 \%$, and that of the ${ }^{2} \mathrm{H}$-labelled fraction was $99.95 \%(0.05 \%$ was unlabelled RAc) with $67.2 \%$ as $\left[{ }^{2} \mathrm{H}_{8}\right] \mathrm{RAc}, 14.1 \%$ as $\left[{ }^{2} \mathrm{H}_{7}\right] \mathrm{RAc}$ and $2.3 \%$ as $\left[{ }^{2} \mathrm{H}_{6}\right] \mathrm{RAc}$. There was about $15 \%$ natural ${ }^{13} \mathrm{C}$ in the $\left[{ }^{2} \mathrm{H}_{8}\right]$ RAc. No correction was made for the $\left[{ }^{2} \mathrm{H}_{8}\right]$ RAc doses in the data analysis.

\section{Subjects}

Subjects were recruited from three rural villages of China's eastern Shandong Province, where the villagers had available plenty of cereal and other vegetable foods in their diets, but only limited animal foods. With the help of village doctors, experimental information and recruitment messages were advertised among the villagers. Forty villagers aged 50-60 years expressed their willingness to be volunteers and after informed consent accepted an extensive physical examination with blood screening. Fifteen volunteers (nine males and six females) were selected upon physical examination and enrolled to participate in the study. Informed written consent for all procedures was obtained from all volunteers under the guidelines established both by the ethical review committee of the Institute of Nutrition and Food Hygiene, Chinese Academy of Preventive Medicine and the institutional review board of Tufts University, New England Medical Center.

All subjects had the following characteristics: 50-60 years old; non-smokers and not having taken vitamin A or $\beta$-carotene supplements or other nutrient supplements within the last month; having body weights within $20 \%$ of their standard weight for height (BMI $\leq 30 \mathrm{~kg} / \mathrm{m}^{2}$ ); absence of symptomatic cardiac disease or uncontrolled hypertension on physical examination; negative tests for Helicobacter pylori and Hepatitis B surface antigen; no parasitism or fat malabsorption (i.e. no parasite eggs on faecal examination and no oil globlets found on microscopic stool inspection using Sudan III); no history of bleeding disorders; no history of gastric, intestinal, liver, pancreatic or renal disease; no portion of the stomach or the intestine surgically removed; no history of intestinal obstruction or malabsorption; no chronic alcoholism; no convulsive disorder; no abnormality in screening blood or urine samples. All subjects had a serum retinol concentration in the lower level of the normal range $(0.7-1.4 \mu \mathrm{mol} / \mathrm{l})$, with seven subjects having serum retinol concentrations lower than $1.0 \mu \mathrm{mol} / \mathrm{l}$.

\section{Study design}

A metabolic research unit was established in the local town (Ji-ning) hospital. A dietitian gave dietary instructions to the subjects to avoid large amounts of carrots, dark green leafy vegetables and liver products as well as alcohol and smoking during 2 weeks of family (free-living) life before entering the experiment. After the 2-week preparation period, participants were housed in the metabolic research unit for a $10 \mathrm{~d}$ residential stay. After this they were once again free-living from the 11th to the 56th day of the study and followed the same dietary instructions. The dietician followed up with all participants on a weekly basis to ensure dietary compliance.

On the morning of day 1 , a fasting serum sample $(10 \mathrm{ml})$ was drawn from each subject. Then at $0 \mathrm{~h}$ each subject ingested ten gelatin capsules containing a total of $6 \mathrm{mg}$ $\left[{ }^{2} \mathrm{H}_{8}\right] \beta$-carotene $(11011 \mathrm{nmol})$ in $6 \mathrm{~g}$ maize oil together with a semi-liquid, retinol- and $\beta$-carotene-free breakfast (soft noodles with soup, with $25 \%$ energy from fat). At $5 \mathrm{~h}$ after the breakfast, the subjects consumed the same semi-liquid diet as a lunch. In the evening $(10 \mathrm{~h}$ after the breakfast) the volunteers received a supper of low $\beta$-carotene (about $0.1 \mathrm{mg}$ ) and vitamin A (about $0.05 \mathrm{mg}$ ) content with $30 \%$ energy as fat (steamed wheat-flour bread, fish and white Chinese cabbage cooked with peanut oil). On the fourth day of the study, the volunteers consumed a capsule containing $3.0 \mathrm{mg}\left[{ }^{2} \mathrm{H}_{8}\right] \mathrm{RAc}(8915 \mathrm{nmol})$ in $170 \mathrm{mg}$ maize oil with the same semi-liquid diets as used before. At $5 \mathrm{~h}$ after the breakfast they consumed the same retinoland $\beta$-carotene-free meal as a lunch, and $10 \mathrm{~h}$ after the breakfast they received the same supper of low $\beta$-carotene and vitamin A content as was used on day 1 . For the first $9 \mathrm{~d}$ of the study, the volunteers were provided all meals of a low $\beta$-carotene and vitamin A content consisting of wheat flour, soyabean tofu, white fish, white chicken meat, and light-coloured vegetables. Serum samples of $10 \mathrm{ml}$ were collected by venepuncture at $0,3,5,7,9,11$, and $13 \mathrm{~h}$ of the $1 \mathrm{st}$ and the 4th days of the experiment, and fasting (overnight) serum samples were also collected on the mornings of the 2nd, 3rd, 5th, 6th, 7th, 8th, 9th, 10th, 14th, 21st, 28th, 35th, 42nd, 49th, and 56th day. 
The experimental scheme of dosing, meals and the timing of blood collections are shown in Fig. 1.

The blood samples were transferred to no-additive tubes covered with Al foil to prevent light damage and set at room temperature $\left(25^{\circ} \mathrm{C}\right)$ for $0.5 \mathrm{~h}$. The samples were then centrifuged at $800 \mathrm{~g}$ for $15 \mathrm{~min}$ at room temperature. Serum was separated, transferred to $2 \mathrm{ml}$ vials and stored at $-20^{\circ} \mathrm{C}$ until the end of the experiment and then transported on dry ice to Beijing and kept at $-70^{\circ} \mathrm{C}$ there, and then to Boston (within 5 months; Craft et al. 1988). The samples were kept at $-70^{\circ} \mathrm{C}$ in Boston until they were analysed (3 months). The serum samples were always kept either in the dark or under red light conditions during processing, transport, and analysis. The serum samples were analysed by the Carotenoids and Health Laboratory of the Jean Mayer US Department of Agriculture HNRCA (Boston, MA, USA).

\section{Methods}

Instrumentation. The HPLC system consisted of two Waters 510 pumps, a Waters 717 plus autosampler, a $\mathrm{YMC} \mathrm{C}_{30}$ column from Waters Inc. (Milford, MA, USA), or a $\mathrm{C}_{18}$ column from Perkin-Elmer Inc. (Norwalk, CT, USA), a model 7950 HPLC column temperature controller (Johnes Chromatography Ltd, Hengoed Mid Glam, Wales, UK), a Waters 994 Programmable Photodiode Array Detector, and a Gilson FC 203 fraction collector (Middletown, WI, USA), supported by a Waters networking Millennium computer system. The detector was set at $340 \mathrm{~nm}$ for retinoids and at $450 \mathrm{~nm}$ for carotenoids (Tang et al. 1993; Yeum et al. 1996).

GC-electron capture negative chemical ionisation (ECNCI)-MS was carried out using an Agilent 5973N (Agilent, Folsom, CA, USA), and the GC column was a DB-1 (Agilent, Folsom, CA, USA). The temperature of the column oven and on-column injector was programmed from $50^{\circ} \mathrm{C}$ to $285^{\circ} \mathrm{C}$ at $15^{\circ} \mathrm{C} / \mathrm{min}$. The $\mathrm{GC}-\mathrm{MS}$ interface temperature was set at $285^{\circ} \mathrm{C}$. He gas was used as the carrier gas for $\mathrm{GC}$. The analytes were detected by a quadrupole mass spectrometer, using $2 \cdot 1 \times 10^{-4}$ torr of methane as the moderator gas for ECNI. The ion source temperature was $150^{\circ} \mathrm{C}$.

LC-APCI-MS was carried out using an Agilent 1100 LC (Andover, MA, USA), equipped with a $\mathrm{C}_{18}$ Prizm column (Keystone Scientific, PA, USA), and a Bruker Esquire LC mass spectrometer (Billerica, MA, USA).

High-performance liquid chromatography analysis of serum samples. Saline $(50 \mu \mathrm{l} ; 0.85 \% \mathrm{NaCl}), 100 \mu \mathrm{l}$ RAc-echinenon in ethanol (as internal standard substances), and $3 \mathrm{ml}$ chloroform-methanol $(2: 1, \mathrm{v} / \mathrm{v})$ were added to $100 \mu \mathrm{l}$ of serum sample. The mixture was vortexed and centrifuged for $10 \mathrm{~min}$ at $4^{\circ} \mathrm{C}$ and at $800 \mathrm{~g}$. The chloroform layer was collected. Hexane $(2 \mathrm{ml})$ was then added to the aqueous layer to re-extract fat-soluble nutrients. The hexane layer was combined with the chloroform layer and evaporated under $\mathrm{N}_{2}$ on an N-EVAP (Organomation Associates, Inc., South Berlin, MA, USA). The residue was dissolved in $100 \mu \mathrm{l}$ ethanol using a $40 \mathrm{~s}$ vortex and $20 \mathrm{~s}$ sonication, and $50 \mu \mathrm{l}$ was injected onto an HPLC

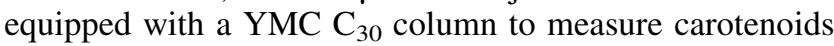
and retinol concentrations (Tang et al. 1993; Yeum et al. 1996; Johnson et al. 2000).

The HPLC mobile phase was methanol-methyl-tertbutyl ether-water $(83: 15: 2$, by vol. (solvent A) or 8:90:2, by vol. (solvent B), with $1.5 \%$ ammonium acetate in the water), as described by Yeum et al. (1996). The concentrations of $\beta$-carotene and retinol were quantified, and, together with the percentage isotopic enrichment of retinol and $\beta$-carotene (determined by GC-MS and LC-MS), were used to calculate the molar enrichments of $\left[{ }^{2} \mathrm{H}_{4}\right.$ ]retinol, $\left[{ }^{2} \mathrm{H}_{8}\right]$ retinol, and $\left[{ }^{2} \mathrm{H}_{8}\right] \beta$-carotene in the processed sera samples.

Gas chromatography-electron capture negative chemical ionisation-mass spectrometry analysis. First, a $200 \mu \mathrm{l}$ serum sample was extracted following the procedure mentioned earlier. The extract residue was re-suspended in $70 \mu \mathrm{l}$ acetonitrile-tetrahydrofuran $(2: 1, \mathrm{v} / \mathrm{v})$, and $50 \mu \mathrm{l}$ of it was injected onto the HPLC equipped with a Perkin-Elmer $\mathrm{C}_{18}$ column to separate the retinol fraction. The mobile phase was acetonitrile-tetrahydrofuran-water with $1.5 \%$ ammonium acetate in water (50:20:30, by vol. (solvent A) or 50:44:6, by vol. (solvent

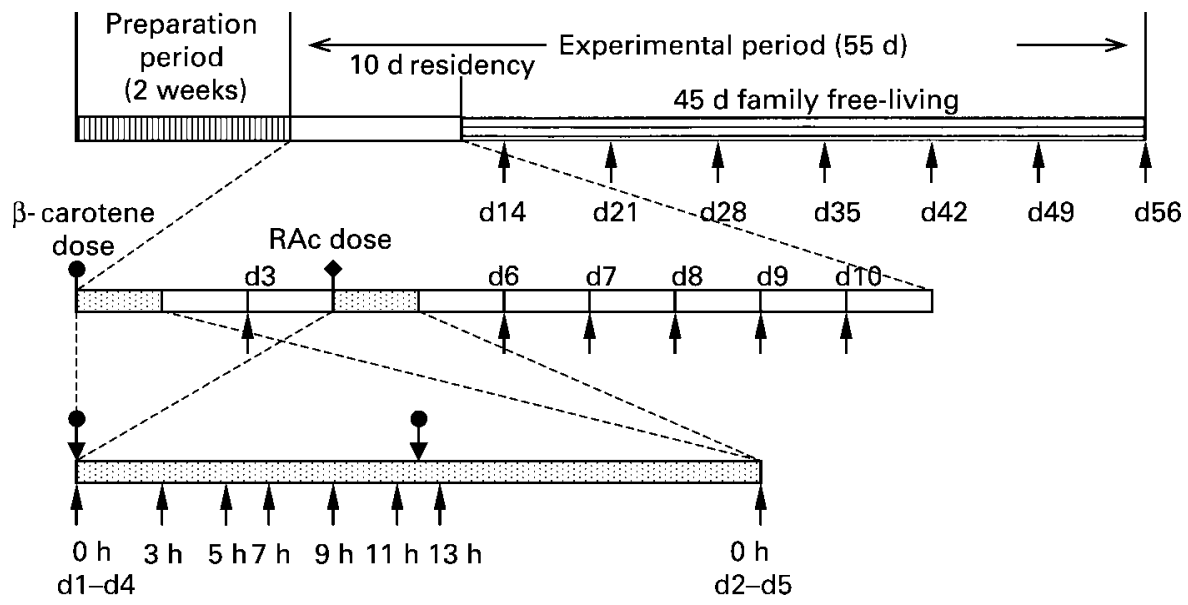

Fig. 1. The experimental scheme of dosing, meals and the timing of blood-sample collection. The experiment covered $55 \mathrm{~d}$, beginning on day 1 (d1) and ending on day 56 (d56). ( $\uparrow$ ), Blood-sample collection; ( $\downarrow$ ), semi-liquid diet; $(\bullet)$, $\beta$-carotene dose; ( $\bullet)$, retinyl acetate (RAc) dose. 
B)) as described by Tang et al. (2003). In this system, the retinol eluted at $10 \mathrm{~min}$. The elution was collected from 9.0 to $11.0 \mathrm{~min}$ by a fraction collector, and dried under $\mathrm{N}_{2} . \mathrm{N}$, O-bis(trimethylsilyl) triflucroacetamide $(40 \mu \mathrm{l})$ with $10 \%$ trimethylchlorosilane (Pierce, Rockford, IL, USA) was added to the residue in the test tube. The tube was capped with a ground glass stopper and was heated at $70^{\circ} \mathrm{C}$ for $30 \mathrm{~min}$. The reaction mixture of retinyl trimethylsilyl ether and the unreacted N, O-bis(trimethylsilyl) triflucroacetamide and trimethylchlorosilane was transferred by a glass pipette to a brown vial with a conical-shaped glass insert and was analysed by GC-ECNCI-MS to determine the enrichment of $\left[{ }^{2} \mathrm{H}_{4}\right]$ retinol and $\left[{ }^{2} \mathrm{H}_{8}\right]$ retinol (Tang et al. 1998, 2003).

The derivatisation reaction mixture $(1 \mu \mathrm{l})$ was injected into the GC-ECNCI-MS. The mass spectrometer was set to scan repetitively between 260 and $280 \mathrm{Da}$. The percentage enrichment of $\left[{ }^{2} \mathrm{H}_{4}\right]$ retinol derived from $\left[{ }^{2} \mathrm{H}_{8}\right] \beta$-carotene was calculated by integrating the peak areas under the re-constructed mass chromatogram of the negative ions at $\mathrm{m} / \mathrm{z} 271\left({ }^{2} \mathrm{H}_{3}\right), 272\left({ }^{2} \mathrm{H}_{4}+{ }^{13} \mathrm{C}_{-}{ }^{2} \mathrm{H}_{3}\right)$ and $273\left({ }^{13} \mathrm{C}_{-}{ }^{2} \mathrm{H}_{4}\right)$ divided by the total area response of the labelled and unlabelled retinol ions. The percentage enrichment of $\left[{ }^{2} \mathrm{H}_{8}\right]$ retinol derived from $\left[{ }^{2} \mathrm{H}_{8}\right]$ RAc was calculated by integrating the peak area under the re-constructed mass chromatogram of the negative ions at $\mathrm{m} / \mathrm{z} 274\left({ }^{2} \mathrm{H}_{6}\right), 275\left({ }^{2} \mathrm{H}_{7}\right), 276$ $\left({ }^{2} \mathrm{H}_{8}\right), 277\left({ }^{13} \mathrm{C}_{-}{ }^{2} \mathrm{H}_{8}\right)$, and $278\left({ }^{13} \mathrm{C}_{2^{-}}{ }^{2} \mathrm{H}_{8}\right)$ divided by the total area response of the labelled and unlabelled retinol fragment ions. The percentage enrichment measured by GC-MS and the concentration of retinol in the serum was used to calculate the concentration of labelled retinol in the circulation (Tang et al. 2003).

Liquid chromatography-atmospheric pressure chemical ionisation-mass spectrometry analysis. A $2 \mathrm{ml}$ serum sample was extracted with chloroform-methanol (2:1, v/ v) as described earlier (Tang et al. 2003). The extract was purified through $\mathrm{NH}_{2}^{-}$cartridge columns using hexane as the eluent. The $\beta$-carotene-hexane eluent was evaporated under $\mathrm{N}_{2}$. The residue was re-suspended in $70 \mu \mathrm{l}$ methyl-tert-butyl ether-methanol $(2: 1, \mathrm{v} / \mathrm{v})$, and $50 \mu \mathrm{l}$ of it was injected onto an HPLC system equipped with a $\mathrm{C}_{30}$ column. The HPLC mobile phase was methanol-methyl-tert-butyl ether-water, and a $\mathrm{C}_{30}$ column was used (Tang et al. 2003).

The $\beta$-carotene fraction from the HPLC separation was collected and dried under $\mathrm{N}_{2}$. The purified $\beta$-carotene fraction was evaporated under $\mathrm{N}_{2}$, re-suspended in ethanol by vortexing and sonication, and injected into an LC-APCIMS. The LC mobile phase was $95 \%$ methanol and $5 \%$ ethanol-methanol-tetrahydrafuron (75:20:5, by vol.). The mass spectrometer was set to scan the range of 535 to $550 \mathrm{Da}$ in $0 \cdot 1-\mathrm{Da}$ steps with a scan speed of 5.25 scans/s. The actual enrichment of labelled $\beta$-carotene in serum was determined at $\mathrm{m} / \mathrm{z}(\mathrm{M}+\mathrm{H})^{+}$of $537\left({ }^{1} \mathrm{H}\right)$, $538\left({ }^{13} \mathrm{C}-{ }^{1} \mathrm{H}\right), 539\left({ }^{13} \mathrm{C}_{-}{ }^{13} \mathrm{C}-{ }^{1} \mathrm{H}\right), 544\left({ }^{2} \mathrm{H}_{7}\right), 545\left({ }^{2} \mathrm{H}_{8}+\right.$ $\left.{ }^{13} \mathrm{C}_{-}{ }^{2} \mathrm{H}_{7}\right), 546\left({ }^{13} \mathrm{C}_{-}{ }^{2} \mathrm{H}_{8},{ }^{13} \mathrm{C}-{ }^{13} \mathrm{C}-{ }^{2} \mathrm{H}_{7}\right)$, and $547\left({ }^{13} \mathrm{C}-{ }^{13} \mathrm{C}-\right.$ ${ }^{2} \mathrm{H}_{8}$ ) with a Bruker Data Analysis Esquire-LC MS Processing, version $1.6 \mathrm{~m}$ (Billerica, MA, USA).

Calculations of areas under the curves of labelled retinol or $\beta$-carotene in the serum. Total serum responses to the $\left[{ }^{2} \mathrm{H}_{8}\right] \beta$-carotene dose and the $\left[{ }^{2} \mathrm{H}_{8}\right] \mathrm{RAc}$ dose were defined by multiplying the total serum volume $(0 \cdot 0435$ of body weight; Diem, 1962) and the concentrations of $\left[{ }^{2} \mathrm{H}_{4}\right]$ retinol, $\left[{ }^{2} \mathrm{H}_{8}\right]$ retinol, and $\left[{ }^{2} \mathrm{H}_{8}\right] \beta$-carotene in the circulation. The areas under the curves (AUC) in nmol $\times \mathrm{d}$ were used to represent total serum responses to the $\left[{ }^{2} \mathrm{H}_{8}\right] \beta$-carotene and the $\left[{ }^{2} \mathrm{H}_{8}\right] \mathrm{RAc}$ doses, and calculated by using the curves of total serum responses $\nu$. time $(\mathrm{nmol} \times \mathrm{d})$ (Tang et al. 2003). The integral calculus of the AUC was carried out using the Integral-Curve of Kaleidagraph (v3.51; Synergy Software, Reading, PA, USA).

Calculations of vitamin A equivalence. It was assumed that $\left[{ }^{2} \mathrm{H}_{4}\right]$ retinol formed from $\left[{ }^{2} \mathrm{H}_{8}\right] \beta$-carotene followed the same serum kinetics as $\left[{ }^{2} \mathrm{H}_{8}\right]$ retinol formed from the quantitatively known $\left[{ }^{2} \mathrm{H}_{8}\right]$ RAc. $\left[{ }^{2} \mathrm{H}_{4}\right]$ retinol formed from the $\beta$-carotene dose was calculated by comparing the AUC of the serum $\left[{ }^{2} \mathrm{H}_{4}\right]$ retinol response and the AUC of the vitamin A reference dose $\left(8915 \mathrm{nmol}\left[{ }^{2} \mathrm{H}_{8}\right] \mathrm{RAc}\right)$. This calculated value yields the retinol equivalence of the $\beta$-carotene dose. The calculating formula is as follows (Tang et al. 2003):

$\left[{ }^{2} \mathrm{H}_{4}\right]$ retinol formed from the $\beta$-carotene dose (nmol)

$$
=\frac{\text { AUC of }\left[{ }^{2} \mathrm{H}_{4}\right] \text { retinol }}{\text { AUC of }\left[{ }^{2} \mathrm{H}_{8}\right] \text { retinol }} \times 8915 \text {. }
$$

Calculations of conversion factor. The amount of a given oral dose of $\beta$-carotene was compared with the amount of vitamin $A$ derived from the $\beta$-carotene dose in order to define the $\beta$-carotene to vitamin A conversion factor by using the following formula (Tang et al. 2003):

\section{Molar conversion factor of $\beta$-carotene to retinol}

\section{$\left[{ }^{2} \mathrm{H}_{8}\right] \beta$-carotene dose (nmol)

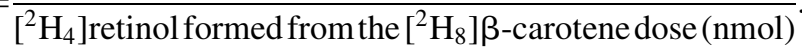

Because the ingested labelled $\beta$-carotene dose was of $90.6 \%$ chemical purity, the amount was corrected from $6 \mathrm{mg}$ to $5.436 \mathrm{mg}$ in calculating the conversion factor of $\beta$-carotene to vitamin A. Therefore, $\beta$-carotene dose $(\mathrm{nmol})=6 \mathrm{mg} \times 90.6 \% / 544.9(\mathrm{mg} / \mathrm{mmol}) \times 10^{6}=$ $9976 \mathrm{nmol}$. There were cis isomers in the labelled $\beta$-carotene doses but they were not a major component of the dose. The contribution of the cis isomers of $\beta$-carotene to the conversion factor was not evaluated separately.

Calculations of the calculated area under the curve of $\left[{ }^{2} \mathrm{H}_{4}\right]$ retinol and post absorption conversion of $\beta$-carotene to retinol. The $\left[{ }^{2} \mathrm{H}_{4}\right]$ retinol formed from the $\left[{ }^{2} \mathrm{H}_{8}\right]$ $\beta$-carotene dose was assumed to follow the same serum kinetics as the $\left.{ }^{2} \mathrm{H}_{8}\right]$ retinol formed from the (quantitatively known) $\left[{ }^{2} \mathrm{H}_{8}\right] \mathrm{RAc}$ dose on the assumption that all $\left[{ }^{2} \mathrm{H}_{4}\right]-$ retinol from the $\left[{ }^{2} \mathrm{H}_{8}\right] \beta$-carotene was produced in the intestine only. The period of $24 \mathrm{~h}$ was chosen as a cut-off time for the intestinal conversion of $\beta$-carotene to retinol. The $\left[{ }^{2} \mathrm{H}_{4}\right]$ retinol: $\left[{ }^{2} \mathrm{H}_{8}\right]$ retinol formed on day 1 value should be constant throughout the whole experiment if no further conversion occurs. Thus, a presumed AUC value over time can be calculated for $\left[{ }^{2} \mathrm{H}_{4}\right]$ retinol based on the AUC of 
$\left[{ }^{2} \mathrm{H}_{8}\right]$ retinol as follows (Tang et al. 2003):

Calculated (presumed) AUC of $\left[{ }^{2} \mathrm{H}_{4}\right]$ retinol at $n \mathrm{~d}$ $=\left(n \mathrm{~d}\right.$ AUC of $\left[{ }^{2} \mathrm{H}_{8}\right]$ retinol $/ 1 \mathrm{~d}$ AUC of $\left[{ }^{2} \mathrm{H}_{8}\right]$ retinol $)$

$$
\times\left(1 \mathrm{~d} \text { AUC of }\left[{ }^{2} \mathrm{H}_{4}\right] \text { retinol }\right) \text {, }
$$

where $n$ is $6,13,20,27,34,41$, and 52 .

The difference of the actual measured AUC of $\left[{ }^{2} \mathrm{H}_{4}\right]-$ retinol and the calculated (presumed) AUC of $\left[{ }^{2} \mathrm{H}_{4}\right]$ retinol was deemed to come from the contribution of post-absorption (i.e. extra-intestinal) conversion of $\left[{ }^{2} \mathrm{H}_{8}\right] \beta$-carotene to retinol. The following formula was used to calculate the percentage post-absorption conversion of $\beta$-carotene to retinol at different time points:

Percentage retinol formed due to post-absorption

$$
\begin{aligned}
\text { conversion }= & 100 \times\left(n \mathrm{~d} \text { AUC of }\left[{ }^{2} \mathrm{H}_{4}\right]\right. \text { retinol } \\
& \left.-n \mathrm{~d} \text { calculated AUC of }\left[{ }^{2} \mathrm{H}_{4}\right] \text { retinol }\right) / n \\
& \mathrm{~d} \text { AUC of }\left[{ }^{2} \mathrm{H}_{4}\right] \text { retinol, }
\end{aligned}
$$

where $n$ is $6,13,20,27,34,41$ and 52 .

Calculations of total liver vitamin A store. The total liver vitamin A store can be estimated when the oral administered dose of ${ }^{2} \mathrm{H}$-labelled vitamin $\mathrm{A}$ becomes equilibrated with the body pool. The equilibration time is reported to be about $19 \mathrm{~d}$ (Furr et al. 1989). The modified Bausch-Rietz equation (Olson, 1986; Furr et al. 1989; Haskell et al. 1998; Tang et al. 2002) was used to estimate the body store of vitamin A using 18, 21, and $25 \mathrm{~d}$ serum $\left[{ }^{2} \mathrm{H}_{4}\right]$ retinol enrichment data.

Data processing and statistical analysis. The unpaired $t$ test was used to compare differences in age, BMI, retinol, and carotenoids $(\beta$-carotene, $\alpha$-carotene, lutein + zeaxanthin, cryptoxanthin, lycopene), as well as differences in the AUC of $\left[{ }^{2} \mathrm{H}_{4}\right]$ retinol, $\left[{ }^{2} \mathrm{H}_{8}\right]$ retinol, and $\left[{ }^{2} \mathrm{H}_{8}\right] \beta$-carotene. It was used to compare equivalents and conversion factors between sexes and between normal converters and poor converters. In addition, ANOVA was used to determine differences among the AUC of $\left[{ }^{2} \mathrm{H}_{4}\right]$ retinol, $\left[{ }^{2} \mathrm{H}_{8}\right]$ retinol and $\left[{ }^{2} \mathrm{H}_{8}\right] \beta$-carotene and the calculated AUC of $\left[{ }^{2} \mathrm{H}_{4}\right]-$ retinol, as well as conversion factors at different days. Systat v9.0 (SAS Institute Inc., Cary, NC, USA) was used for statistical calculations. A difference was considered to be significant at $P \leq 0.05$.

\section{Results}

The characteristics of the subjects and their baseline serum concentrations of retinol and carotenoids are presented in Table 1. There were no significant differences between the sexes for age, BMI, serum retinol, $\beta$-carotene, $\alpha$-carotene, lutein + zeaxanthin, cryptoxanthin, or lycopene.

The serum response and conversion factor at $52 d$ after the dose

Individual data of sex, age, BMI, and AUC of $\left[{ }^{2} \mathrm{H}_{8}\right] \beta$-carotene, AUC of $\left[{ }^{2} \mathrm{H}_{4}\right]$ retinol from the $\left[{ }^{2} \mathrm{H}_{8}\right] \beta$-carotene dose, AUC of $\left[{ }^{2} \mathrm{H}_{8}\right]$ retinol from the $\left[{ }^{2} \mathrm{H}_{8}\right]$ RAc dose, vitamin $\mathrm{A}$ equivalent of the $\left[{ }^{2} \mathrm{H}_{8}\right] \beta$-carotene dose as well as the calculated conversion factors of $\beta$-carotene to retinol on a molar basis and by weight at $52 \mathrm{~d}$ for each subject are presented in Table 2.

All fifteen subjects responded well to the $\left[{ }^{2} \mathrm{H}_{8}\right] \mathrm{RAc}$ reference dose. AUC of $\left[{ }^{2} \mathrm{H}_{8}\right]$ retinol formed from the $\left[{ }^{2} \mathrm{H}_{8}\right] \mathrm{RAc}$ dose in all subjects ranged from 1994 to $7304 \mathrm{nmol} \times \mathrm{d}$, as shown in Table 2. However, the responses to the $\left[{ }^{2} \mathrm{H}_{8}\right] \beta$-carotene dose differed greatly with AUC of $\left[{ }^{2} \mathrm{H}_{4}\right]$ retinol ranging from 39 to $2545 \mathrm{nmol}$ $\times \mathrm{d}$. The responses of subjects no. $4,11,14$ and 15 to the $\left[{ }^{2} \mathrm{H}_{8}\right] \beta$-carotene dose were very low, as presented in Table 2. The poor responses of the four subjects to the $\left[{ }^{2} \mathrm{H}_{8}\right] \beta$-carotene dose were first speculated to be due to interference at $\mathrm{m} / \mathrm{z} 272$ of the chromatograph in the GCMS analysis. However, repeated GC-MS analysis on their serum samples showed a clear and weak $\left[{ }^{2} \mathrm{H}_{4}\right]$ retinol peak, suggesting that these four subjects responded much less robustly to an oral dose of $\left[{ }^{2} \mathrm{H}_{8}\right] \beta$-carotene. Here, the four poor converters were termed as poor converters (see later) and separated from the other subjects in the data analysis. The statistical results for all subjects, the eleven normal converters, and the four poor converters are each presented in Table 2 . The average conversion factors after a $6 \mathrm{mg} \beta$-carotene dose for all subjects (nine males and six females) were 15.6 (SD 19.8):1 (range of $2 \cdot 0: 1$ to $58 \cdot 1: 1$ ) on a molar basis and $29 \cdot 3$ (SD 37.2):1

\begin{tabular}{|c|c|c|c|c|c|c|}
\hline & \multicolumn{2}{|c|}{ Male $(n 9)$} & \multicolumn{2}{|c|}{ Female $(n 6)$} & \multicolumn{2}{|c|}{ Total $(n 15)$} \\
\hline & Mean & SD & Mean & SD & Mean & SD \\
\hline Age (years) & $56 \cdot 4$ & $3 \cdot 8$ & 53.2 & $2 \cdot 4$ & $55 \cdot 1$ & $3 \cdot 6$ \\
\hline $\mathrm{BMI}\left(\mathrm{kg} / \mathrm{m}^{2}\right)$ & 23.8 & 2.9 & $27 \cdot 0$ & 4.1 & $25 \cdot 1$ & $3 \cdot 7$ \\
\hline Retinol $(\mu \mathrm{mol} / \mathrm{l})$ & $1 \cdot 3$ & 0.5 & $1 \cdot 0$ & 0.2 & $1 \cdot 2$ & 0.4 \\
\hline$\beta$-Carotene $(\mu \mathrm{mol} / \mathrm{l})$ & 0.30 & 0.15 & 0.38 & $0 \cdot 16$ & 0.33 & 0.15 \\
\hline$\alpha$-Carotene $(\mu \mathrm{mol} / \mathrm{l})$ & 0.02 & 0.01 & 0.03 & 0.01 & 0.02 & 0.01 \\
\hline Lutein and zeaxanthin $(\mu \mathrm{mol} / \mathrm{l})$ & 0.6 & 0.2 & 0.6 & 0.2 & 0.6 & 0.2 \\
\hline Cryptoxanthin (nmol/l) & 68.5 & $37 \cdot 0$ & $120 \cdot 1$ & 63.4 & $89 \cdot 1$ & 53.9 \\
\hline Lycopene (nmol/l) & 1.9 & $2 \cdot 0$ & $3 \cdot 1$ & $3 \cdot 1$ & $2 \cdot 4$ & 2.5 \\
\hline
\end{tabular}

Table 1. Subject characteristics and fasting serum concentrations of retinol and carotenoids at the beginning of the study

(Mean values and standard deviations) 
Table 2. Serum response areas under the curves (AUC) of $\left[{ }^{2} \mathrm{H}_{8}\right] \beta$-carotene, $\left[{ }^{2} \mathrm{H}_{4}\right]$ retinol (from the $\left[{ }^{2} \mathrm{H}_{8}\right] \beta$-carotene dose) and $\left[{ }^{2} \mathrm{H}_{8}\right]$ retinol (from the $\left[^{2} \mathrm{H}_{8}\right]$ retinyl acetate (RAc) dose), and calculated retinol equivalents and conversion factors of $\left.{ }^{2} \mathrm{H}_{8}\right] \beta$-carotene to vitamin $\mathrm{A}$ of fifteen subjects at $52 \mathrm{~d}$ after the doses

\begin{tabular}{|c|c|c|c|c|c|c|c|c|c|}
\hline \multirow{2}{*}{$\begin{array}{l}\text { Subject } \\
\text { no. }\end{array}$} & \multirow[b]{2}{*}{ Sex } & \multirow[b]{2}{*}{ Age } & \multirow[b]{2}{*}{ BMI } & \multirow{2}{*}{$\begin{array}{c}\text { AUC of } \\
{\left[{ }^{2} \mathrm{H}_{8}\right] \beta \text {-carotene }} \\
\text { at } 52 \mathrm{~d}(\mathrm{nmol} \times \mathrm{d})\end{array}$} & \multirow{2}{*}{$\begin{array}{c}\text { AUC of }\left[{ }^{2} \mathrm{H}_{4}\right] \text { retinol } \\
\text { from }\left[{ }^{2} \mathrm{H}_{8}\right] \beta \text {-carotene } \\
\text { dose at } 52 \mathrm{~d}(\mathrm{nmol} \times \mathrm{d})\end{array}$} & \multirow{2}{*}{$\begin{array}{c}\text { AUC of } \\
{\left[{ }^{2} \mathrm{H}_{8}\right] \text { retinol from }} \\
{\left[{ }^{2} \mathrm{H}_{8}\right] \text { RAc dose }} \\
\text { at } 52 \mathrm{~d}(\mathrm{nmol} \times \mathrm{d})\end{array}$} & \multirow{2}{*}{$\begin{array}{c}\text { Vitamin A } \\
\text { equivalents }\end{array}$} & \multicolumn{2}{|c|}{ Conversion factor } \\
\hline & & & & & & & & By mol & By weight \\
\hline \multicolumn{10}{|c|}{ Normal converters (eleven subjects; seven males and four females) } \\
\hline 1 & Male & 50 & $24 \cdot 0$ & 538 & 653 & 4044 & 1441 & $6 \cdot 9$ & $13 \cdot 0$ \\
\hline 2 & Male & 60 & $20 \cdot 8$ & 986 & 283 & 3080 & 819 & $12 \cdot 2$ & $22 \cdot 9$ \\
\hline 3 & Male & 50 & $23 \cdot 8$ & 1301 & 1888 & 5119 & 3288 & 3.0 & $5 \cdot 7$ \\
\hline 6 & Male & 56 & $23 \cdot 2$ & 1233 & 806 & 3750 & 1917 & $5 \cdot 2$ & $9 \cdot 8$ \\
\hline 7 & Male & 60 & $20 \cdot 3$ & 1498 & 714 & 3748 & 1698 & 5.9 & $11 \cdot 0$ \\
\hline 8 & Male & 60 & $21 \cdot 6$ & 1186 & 621 & 2338 & 2369 & $4 \cdot 2$ & 7.9 \\
\hline 9 & Female & 57 & $28 \cdot 6$ & 2877 & 1376 & 3282 & 3737 & 2.7 & $5 \cdot 0$ \\
\hline 10 & Female & 53 & $28 \cdot 8$ & 1324 & 913 & 3626 & 2244 & 4.5 & $8 \cdot 3$ \\
\hline 12 & Female & 51 & 23.7 & 1642 & 868 & 2772 & 2793 & 3.6 & $6 \cdot 7$ \\
\hline 13 & Female & 55 & 29.9 & 2255 & 1460 & 3926 & 3315 & 3.0 & $5 \cdot 7$ \\
\hline Mean & & $55 \cdot 6$ & $24 \cdot 7$ & 1533 & 1102 & 3659 & 2599 & $4 \cdot 8$ & $9 \cdot 1$ \\
\hline \multicolumn{10}{|c|}{ Poor converters (four subjects; two males and two females) $\dagger$} \\
\hline 4 & Male & 54 & $24 \cdot 2$ & 682 & 129 & 4208 & 273 & $36 \cdot 6$ & $68 \cdot 7$ \\
\hline 11 & Female & 51 & $27 \cdot 9$ & 1174 & 77 & 2022 & 342 & $29 \cdot 2$ & $54 \cdot 8$ \\
\hline 14 & Female & 52 & $20 \cdot 6$ & 526 & 39 & 1994 & 175 & $56 \cdot 9$ & $106 \cdot 9$ \\
\hline 15 & Male & 53 & $30 \cdot 0$ & 259 & 141 & 7304 & 172 & $58 \cdot 1$ & $109 \cdot 1$ \\
\hline Mean & & $52 \cdot 5$ & $25 \cdot 6$ & $660^{*}$ & $97^{*}$ & 3882 & $240^{\star *}$ & $45 \cdot 2^{\star \star}$ & $84 \cdot 9^{\star \star}$ \\
\hline SD & & $1 \cdot 3$ & $4 \cdot 2$ & 384 & 47 & 2506 & 82 & 14.5 & $27 \cdot 3$ \\
\hline \multicolumn{10}{|c|}{ All subjects (fifteen subjects; nine males and six females) } \\
\hline Mean & & $54 \cdot 8$ & $25 \cdot 0$ & 1300 & 834 & 3718 & 1970 & $15 \cdot 6$ & $29 \cdot 3$ \\
\hline SD & & 3.8 & 3.7 & 670 & 723 & 1341 & 1470 & $19 \cdot 8$ & $37 \cdot 2$ \\
\hline
\end{tabular}

Mean value is significantly different to that for normal converters: ${ }^{*} P<0.05,{ }^{* \star} P<0.01$ (independent samples $t$ test).

$\dagger$ The subjects were termed as poor converters who exhibited conversion factors of $\beta$-carotene to retinol as $>29 \cdot 0: 1$ by mol.

(range of $3 \cdot 8: 1$ to $109 \cdot 1: 1$ ) on a weight basis. However, as noted earlier, since the conversion factors did not fall into a normal distribution, subjects who exhibited conversion factors $>29 \cdot 0: 1$ on a molar basis were designated as poor converters, and special attention was paid to them. In the four poor converters (two males and two females), the homologous conversion factors were $45 \cdot 2$ (SD 14.5):1 (range of 29.2: to $58 \cdot 1: 1$ ) on a molar basis, and 84.9 (SD 27.3):1 (range of $54 \cdot 8$ : to $109 \cdot 1: 1$ ) on a weight basis. In the eleven normal converters (seven males and four females), the average conversion factors of $\beta$-carotene to retinol was $4 \cdot 8$ (SD 2.8):1 (range of $2 \cdot 0: 1$ to $12 \cdot 2: 1$ ) on a molar basis and 9.1 (SD 5.3):1 (range of 3.8:1 to 22.9:1) on a weight basis. The inclusion of the data from the four subjects who were poor converters made the standard deviation much greater. The serum response curves after the $\left[{ }^{2} \mathrm{H}_{8}\right] \beta$-carotene dose and the $\left[{ }^{2} \mathrm{H}_{8}\right]$ RAc reference dose of one representative 'normal converter' subject are presented in Fig. 2 and one representative 'poor converter' subject in Fig. 3.

The mean serum responses of the $52 \mathrm{~d} \mathrm{AUC}$ of $\left[{ }^{2} \mathrm{H}_{8}\right] \beta$ carotene and the AUC of $\left[{ }^{2} \mathrm{H}_{4}\right]$ retinol formed from the $\left[{ }^{2} \mathrm{H}_{8}\right] \beta$-carotene dose, and the AUC of $\left[{ }^{2} \mathrm{H}_{8}\right]$ retinol formed from the $\left[{ }^{2} \mathrm{H}_{8}\right]$ RAc dose showed no significant difference between males and females, either among all subjects or the eleven normal converters. Further, no significant correlation was found between the conversion factors and BMI, age, or baseline levels of retinol and carotenoids.

\section{Comparison between the normal converters and the poor converters}

From the comparison between the four poor converters and the eleven normal converters (Table 2), no significant difference was found in age, BMI, baseline retinol, baseline carotenoids, and none had intestinal parasites or fat malabsorption. Also, no significant differences were found in the baseline concentrations of serum retinol and carotenoids between the poor converters and the normal converters. The four poor converters exhibited a similar average serum response AUC of $\left[{ }^{2} \mathrm{H}_{8}\right]$ retinol from the $\left[{ }^{2} \mathrm{H}_{8}\right]$ RAc dose at $52 \mathrm{~d}(3882(\mathrm{SD} 2506) \mathrm{nmol} \times \mathrm{d})$ as compared with the eleven normal converters $(3659($ SD 787$)$ nmol $\times$ d). However, the average $52 \mathrm{~d}$ AUC of $\left[{ }^{2} \mathrm{H}_{4}\right]$ retinol from the $\left[{ }^{2} \mathrm{H}_{8}\right] \beta$ carotene dose $(97(\mathrm{SD} 47) \mathrm{nmol} \times \mathrm{d})$ and the average AUC of $\left[{ }^{2} \mathrm{H}_{8}\right] \beta$-carotene $(660(\mathrm{SD} 384) \mathrm{nmol} \times \mathrm{d})$ in the poor converters was significantly lower than that in the normal converters (1102 (SD 658) and $1533(\mathrm{SD} 646) \mathrm{nmol} \times \mathrm{d}$, respectively) (both $P<0 \cdot 05$ ). Therefore, the average conversion factor of $\beta$-carotene to retinol in the normal converters (4.8 (SD 2.8):1 on a molar basis) was as about ten times more efficient than in the poor converters $(45 \cdot 2$ (SD 14.5): 1 on a molar basis) $(P<0 \cdot 01)$.

\section{$\beta$-Carotene post-absorption conversion}

The AUC of total $\left[{ }^{2} \mathrm{H}_{8}\right]$ retinol from the $\left[{ }^{2} \mathrm{H}_{8}\right]$ RAc dose and $\left[{ }^{2} \mathrm{H}_{4}\right]$ retinol from the $\left[{ }^{2} \mathrm{H}_{8}\right] \beta$-carotene dose at $1,6,13,20$, 

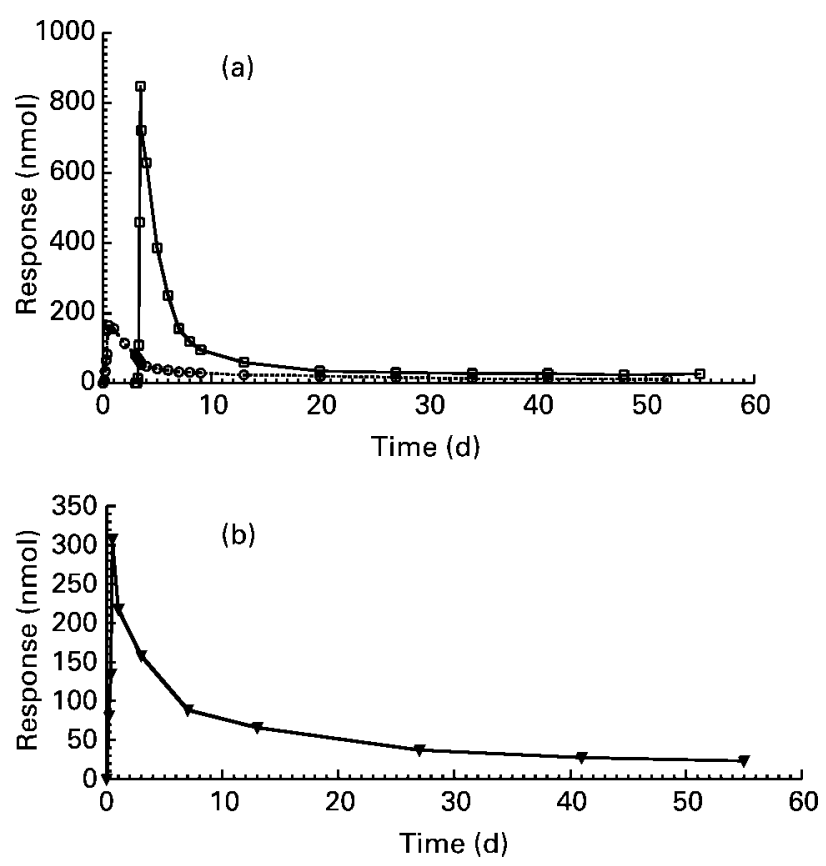

Fig. 2. Serum response curves of (a) $\left[{ }^{2} \mathrm{H}_{4}\right]$ retinol $(-\mathrm{O}-),\left[{ }^{2} \mathrm{H}_{8}\right]$ retinol (-口-), and (b) $\left[{ }^{2} \mathrm{H}_{8}\right] \beta$-carotene $(-\nabla-)$, after dosing with $6 \mathrm{mg}\left[{ }^{2} \mathrm{H}_{8}\right] \beta$-carotene (day 0 ) and $3 \mathrm{mg}\left[{ }^{2} \mathrm{H}_{8}\right]$ retinyl acetate (day 3 ) in one representative normal converter subject (subject no. 9).

$27,34,41$, and $52 \mathrm{~d}$ after the corresponding doses are presented in Table 3. All the AUC increased over time. But the increase of the AUC of $\left[{ }^{2} \mathrm{H}_{4}\right]$ retinol over time was more than that of the AUC of $\left[{ }^{2} \mathrm{H}_{8}\right]$ retinol over time. This result indicates that there was an additional postintestinal retinol formation from the $\left[{ }^{2} \mathrm{H}_{8}\right] \beta$-carotene over time. This additional $\left[{ }^{2} \mathrm{H}_{4}\right]$ retinol formed after intestinal conversion can be estimated by using the difference of
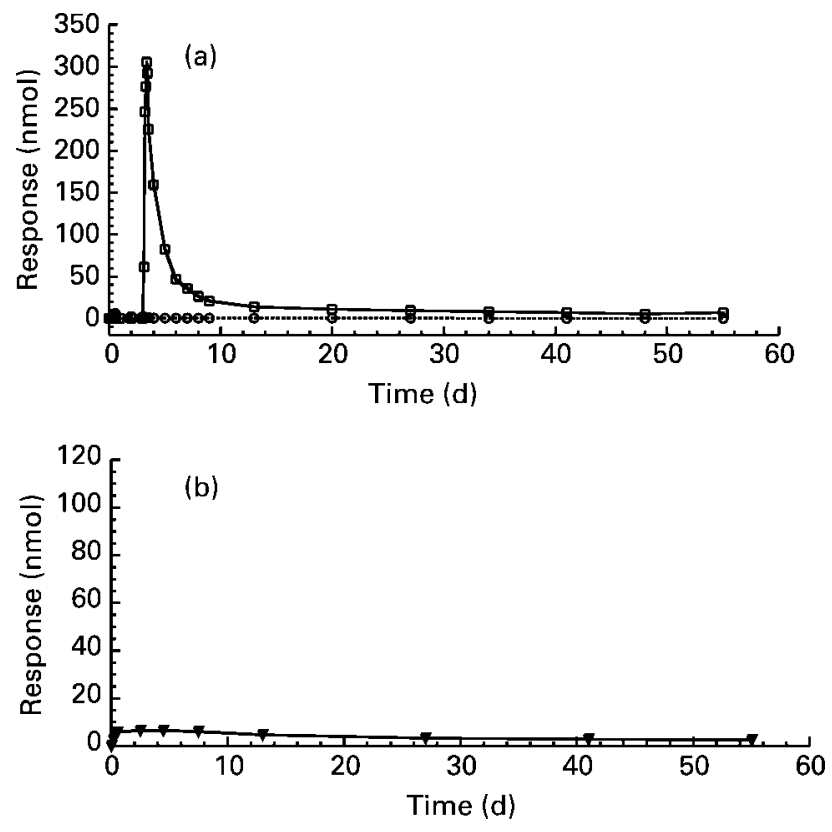

Fig. 3. Serum response curves of (a) $\left[{ }^{2} \mathrm{H}_{4}\right]$ retinol $(-\bigcirc-)$, $\left[{ }^{2} \mathrm{H}_{8}\right]$ retinol $(-\square-)$, and (b) $\left[{ }^{2} \mathrm{H}_{8}\right] \beta$-carotene $(-\nabla-)$, after dosing with $6 \mathrm{mg}\left[{ }^{2} \mathrm{H}_{8}\right] \beta$-carotene (day 0 ) and $3 \mathrm{mg}\left[{ }^{2} \mathrm{H}_{8}\right]$ retinyl acetate (day 3 ) in one representative poor converter subject (subject no. 14). the actual measured AUC of $\left[{ }^{2} \mathrm{H}_{4}\right]$ retinol and the calculated AUC of $\left[{ }^{2} \mathrm{H}_{4}\right]$ retinol. It is reasonable to use $1 \mathrm{~d}$ as a cut-off time to define the intestinal conversion of $\beta$-carotene (Tang et al. 2003). This additional $\left[{ }^{2} \mathrm{H}_{4}\right]$ retinol accounted for $19 \cdot 7,22 \cdot 7,26 \cdot 3,27 \cdot 8,28 \cdot 6,29.5$ and $30.1 \%$ of the total converted retinol at $6,13,20,27,34,41$, and $53 \mathrm{~d}$ after the $\beta$-carotene dose, respectively $(P<0 \cdot 05)$.

The average total conversion factors at $1,6,13,20,27$, 34,41 and $53 \mathrm{~d}$ were $7 \cdot 0$ (SD 3.3), $5 \cdot 6$ (SD 2.7), $5 \cdot 3$ (SD 2.9), $5 \cdot 1$ (SD 2.8), 5.0 (SD 3.0), 4.9 (SD 2.9), 4.9 (SD 2.9) and 4.8 (SD 2.8):1 on a molar basis, respectively. Although these factors were not statistically different $(P>0.05)$ due to relatively large standard deviations, it is obvious that the trend toward better conversion with time was due to additional post-intestinal $\beta$-carotene conversion.

\section{The total liver vitamin A store}

The average values of the calculated total liver vitamin A stores $(\mu \mathrm{mol})$ based on 18,21 , and $25 \mathrm{~d}\left[{ }^{2} \mathrm{H}_{8}\right]$ retinol enrichment data are: 212 (SD 92), 227 (SD 90), and 250 (SD 91), respectively for the eleven normal converters; 275 (SD 183), 296 (SD 195), and 326 (SD 211), respectively for the four poor converters; 229 (SD 119), 245 (SD 122), and 270 (SD 129), respectively for all the subjects. The differences among values of total liver vitamin A stores based on 18,21 , and $25 \mathrm{~d}\left[{ }^{2} \mathrm{H}_{8}\right]$ retinol enrichment data did not reach statistical significance for the normal converters $v$. the poor converters $v$. all subjects (one-way ANOVA, both $P>0.05$ ). No difference was found between the total liver vitamin A stores in the normal converters and the poor converters at different time points (unpaired $t$ test, both $P>0.05)$.

\section{Discussion}

Fifteen healthy volunteers aged 50-60 years were selected from rural villages of eastern China, and given each a high physiological dose $\left(6 \mathrm{mg}\right.$ in oil) of $\left[{ }^{2} \mathrm{H}_{8}\right] \beta$-carotene and $\left[{ }^{2} \mathrm{H}_{8}\right]$ RAc (3 mg in oil) as a vitamin A reference dose to evaluate the conversion efficiency of $6 \mathrm{mg} \beta$-carotene to vitamin $A$. The average intake of dietary carotenoids by the Chinese population is $2.9 \mathrm{mg} / \mathrm{d}$ based on the 1992 National Nutrition Survey (Institute of Nutrition and Food Hygiene, Chinese Academy of Preventive Medicine, 1996). The labelled $\beta$-carotene or vitamin A in oil capsules was ingested together with a designed diet consisting of local foods with $25 \%$ energy from fat. These farmer volunteers had plenty of cereal and other vegetable foods available, but very limited animal foods in their usual diets. They had a range of baseline serum retinol concentrations between 0.70 and $1.40 \mu \mathrm{mol} / 1(200-400 \mu \mathrm{g} / \mathrm{l}$ ) (seven of them had concentrations $<1.0 \mu \mathrm{mol} / \mathrm{l}$, indicating that they were in marginal to low normal vitamin A status; Chinese Nutrition Society, 2000).

In the present experiment, the mean $52 \mathrm{~d}$ conversion factor of $\beta$-carotene to vitamin $A$ at a dose level of $6 \mathrm{mg}$ was 29.3 (SD 37.2):1 by weight. Because of the very poor conversion in four volunteers, the inclusion of these poor converters made the $\beta$-carotene conversion data asymmetrically distributed and the mean value was difficult to 
Table 3. Serum response areas under the curves (AUC) of $\left[{ }^{2} \mathrm{H}_{4}\right]$ retinol and $\left[{ }^{2} \mathrm{H}_{8}\right]$ retinol at $1,6,13,20,27,34,41$ and $52 \mathrm{~d}$ after the $\left[{ }^{2} \mathrm{H}_{8}\right] \beta-$ carotene and $\left[^{2} \mathrm{H}_{8}\right]$ retinyl acetate (RAc) doses, and the percentage of post-absorption conversion and the conversion factors of $\beta$-carotene to retinol at different days for eleven normal converters (seven males and four females)

(Mean values and standard deviations)

\begin{tabular}{|c|c|c|c|c|c|c|c|c|c|c|}
\hline \multirow[b]{2}{*}{ Study day } & \multicolumn{2}{|c|}{$\begin{array}{l}\text { AUC of }\left[{ }^{2} \mathrm{H}_{8}\right] \\
\text { retinol from } \\
{\left[{ }^{2} \mathrm{H}_{8}\right] \mathrm{RAC} c^{\star \star *}} \\
(\mathrm{nmol} \times \text { day })\end{array}$} & \multicolumn{2}{|c|}{$\begin{array}{l}\text { AUC of }\left[{ }^{2} \mathrm{H}_{4}\right] \\
\text { retinol from }\left[{ }^{2} \mathrm{H}_{8}\right] \\
\beta \text {-carotene }{ }^{* \star \star} \\
(\mathrm{nmol} \times \mathrm{d})\end{array}$} & \multicolumn{2}{|c|}{$\begin{array}{l}\text { Calculated } \\
\text { AUC of }\left[^{2} \mathrm{H}_{4}\right] \\
\text { retinol*** } \\
(\mathrm{nmol} \times \mathrm{d})\end{array}$} & \multicolumn{2}{|c|}{$\begin{array}{c}\text { Retinol derived } \\
\text { from post-absor- } \\
\text { ption conversion } \\
(\%)^{\star *} \ddagger\end{array}$} & \multicolumn{2}{|c|}{$\begin{array}{c}\beta \text {-carotene } \\
\text { conversion factor } \\
\text { ratio (on a molar } \\
\text { basis) }^{*}\end{array}$} \\
\hline & $\overline{\text { Mean }}$ & $\overline{S D}$ & Mean & $\overline{S D}$ & $\overline{\text { Mean }}$ & $\mathrm{SD}$ & Mean & $S D$ & Mean & SD \\
\hline 1 & 556 & 87 & 110 & 66 & - & - & 0 & & $7 \cdot 1$ & 3.4 \\
\hline 6 & 1850 & 332 & 483 & 327 & 378 & 248 & 19.7 & $17 \cdot 8$ & $5 \cdot 6$ & $2 \cdot 7$ \\
\hline 13 & 2404 & 495 & 653 & 415 & 496 & 337 & $22 \cdot 7$ & 20.5 & 5.4 & 2.9 \\
\hline 20 & 2730 & 579 & 777 & 484 & 564 & 391 & $26 \cdot 3$ & $21 \cdot 2$ & $5 \cdot 1$ & $2 \cdot 8$ \\
\hline 27 & 2979 & 621 & 871 & 534 & 615 & 424 & $27 \cdot 8$ & 22.7 & $5 \cdot 0$ & 3.0 \\
\hline 34 & 3202 & 664 & 945 & 572 & 661 & 457 & 28.6 & $22 \cdot 7$ & $5 \cdot 0$ & 2.9 \\
\hline 41 & 3382 & 724 & 1012 & 613 & 700 & 491 & 29.5 & $22 \cdot 8$ & 4.9 & 2.9 \\
\hline 52 & 3659 & 787 & 1102 & 658 & 758 & 533 & 30.1 & $22 \cdot 1$ & 4.8 & $2 \cdot 8$ \\
\hline
\end{tabular}

Significance of differences between days by ANOVA: ${ }^{*} \mathrm{NS},{ }^{\star *} P<0.05,{ }^{* \star \star} P<0.001$.

† Calculated AUC of $\left[{ }^{2} \mathrm{H}_{4}\right]$ retinol at $n \mathrm{~d}=\left(n \mathrm{~d} \mathrm{AUC}\right.$ of $\left[{ }^{2} \mathrm{H}_{8}\right]$ retinol/1 d AUC of $\left[{ }^{2} \mathrm{H}_{8}\right]$ retinol $) \times\left(1 \mathrm{~d} \mathrm{AUC}\right.$ of $\left.\left[{ }^{2} \mathrm{H}_{4}\right] \mathrm{retinol}\right)$, where $n$ is $6,13,20,27,34,41$ and 52 $\ddagger$ Percentage retinol of post-absorption conversion $=\left(n \mathrm{~d} \mathrm{AUC} \mathrm{of}\left[{ }^{2} \mathrm{H}_{4}\right]\right.$ retinol $-n \mathrm{~d}$ calculated AUC of $\left[^{2} \mathrm{H}_{4}\right]$ retinol $) / n \mathrm{~d} \mathrm{AUC}$ of $\left.{ }^{2} \mathrm{H}_{4}\right]$ retinol, where $n$ is $6,13,20$,

$27,34,41$ and 52

interpret. Thus, the four poor converters were separated from the other normal converters in the data analysis. The mean $52 \mathrm{~d}$ conversion factor of $6 \mathrm{mg} \beta$-carotene to vitamin $\mathrm{A}$ in the eleven normal converters was 9.1 (SD $5 \cdot 3$ ): 1 by weight, with the highest conversion efficiency factor being 3.8:1 and the lowest conversion efficiency factor being $22 \cdot 8: 1$ by weight, whereas the four poor converters had a mean $52 \mathrm{~d}$ conversion factor of 84.9 (SD 27.3): 1 by weight. The results from the eleven normal converters are similar to those previously reported by Tang et al. (2003) in American adults using the same methodology. These authors reported a $53 \mathrm{~d}$ conversion factor after a $6 \mathrm{mg} \beta$-carotene dose in oil of 9.1:1 (by weight) with a variation from $2 \cdot 4: 1$ to $20: 1$ in twenty-two volunteers aged 40-70 years (twelve females and ten agematched males). However, there are some interesting differences between the American subjects studied by Tang et al. (2003) $\nu$. the Chinese subjects from the present experiment.

First, while the normal converters in the present study exhibited a similar efficiency of $\beta$-carotene conversion to vitamin $\mathrm{A}$, as indicated by the average conversion factor of $9 \cdot 1$ as in the normal converter Chinese subjects, the mean serum response AUC of $\left[{ }^{2} \mathrm{H}_{4}\right]$ retinol after the $\left[{ }^{2} \mathrm{H}_{8}\right] \beta$-carotene dose in the Chinese normal converters $(1102(\mathrm{SD} 658) \mathrm{nmol} \times \mathrm{d}$ for $52 \mathrm{~d})$ was almost double that seen in the American subjects (569 (SD 385) nmol $\times$ $\mathrm{d}$ for $53 \mathrm{~d}$ ). Similarly, the mean serum response AUC of $\left[{ }^{2} \mathrm{H}_{8}\right]$ retinol after the $\left[{ }^{2} \mathrm{H}_{8}\right]$ RAc dose in the normal converter Chinese subjects was almost double that seen in the American subjects $(3659(\mathrm{SD} 787) \mathrm{nmol} \times \mathrm{d}$ for $52 \mathrm{~d}$ in the Chinese $v .1798$ (SD 1139) nmol $\times \mathrm{d}$ for $53 \mathrm{~d}$ in the Americans), as presented in Table 4 . Even the poor converters had much greater AUC of $\left[{ }^{2} \mathrm{H}_{8}\right]$ retinol. The average serum ${ }^{2} \mathrm{H}_{8}$ response curves both for the Chinese and the American subjects, as illustrated in Fig. 4, show that the $\left[{ }^{2} \mathrm{H}_{8}\right]$ retinol enrichment of the Chinese subjects reached a peak at as high as $800 \mathrm{nmol}$, whereas that of the American subjects only reached a peak of one half that, about $400 \mathrm{nmol}$. Compared with the data from the American subjects, the doubled AUC of $\left[{ }^{2} \mathrm{H}_{4}\right]$ retinol and $\left[{ }^{2} \mathrm{H}_{8}\right]$ retinol in the Chinese normal converters produced a comparative conversion factor but slightly less vitamin A equivalents (2599 (SD 1180) $\nu$. 3414 (SD 2298) nmol, NS), as seen in Table 4. The reason for the doubled AUC of $\left[{ }^{2} \mathrm{H}_{4}\right]$ retinol and the doubled AUC of $\left[{ }^{2} \mathrm{H}_{8}\right]$ retinol in the Chinese subjects as compared

Table 4. Comparison of areas under the curves (AUC) of $\left[{ }^{2} \mathrm{H}_{4}\right]$ retinol from the $\left[{ }^{2} \mathrm{H}_{8}\right] \beta$-carotene dose and $\left[{ }^{2} \mathrm{H}_{8}\right]$ retinol from the $\left[{ }^{2} \mathrm{H}_{8}\right]$ retinyl acetate $(\mathrm{RAc})$ dose, as well as vitamin $\mathrm{A}$ equivalents and conversion factor of $\beta$-carotene to vitamin $\mathrm{A}$ between the eleven normal converters in the present study and the American volunteers in the Tang et al. (2003) study

(Mean values, standard deviations and ranges)

\begin{tabular}{|c|c|c|c|c|c|c|}
\hline \multirow{2}{*}{ Data sources ... } & \multicolumn{3}{|c|}{$\begin{array}{l}\text { Tang et al. (2003) } \\
(n 22, \text { time }=53 \mathrm{~d})\end{array}$} & \multicolumn{3}{|c|}{$\begin{array}{c}\text { Present paper } \\
(n 15, \text { time }=52 \mathrm{~d})\end{array}$} \\
\hline & Mean & SD & Range & Mean & SD & Range \\
\hline AUC of $\left[{ }^{2} \mathrm{H}_{4}\right]$ retinol from $\left[{ }^{2} \mathrm{H}_{8}\right] \beta$-carotene dose $(\mathrm{nmol} \times \mathrm{d})^{*}$ & 569 & 385 & $144-1535$ & 1102 & 658 & $283-2545$ \\
\hline AUC of $\left[{ }^{2} \mathrm{H}_{8}\right]$ retinol from $\left[{ }^{2} \mathrm{H}_{8}\right]$ RAc dose $(\mathrm{nmol} \times \mathrm{d})^{*}$ & 1798 & 1139 & $618-5123$ & 3659 & 787 & $2338-5119$ \\
\hline Vitamin A equivalents (nmol) & 3414 & 2298 & $1021-8478$ & 2599 & 1180 & $819-4974$ \\
\hline \multicolumn{7}{|l|}{ Conversion factor: } \\
\hline By weight & $9 \cdot 1$ & $5 \cdot 7$ & $2 \cdot 4-20 \cdot 2$ & $9 \cdot 1$ & $5 \cdot 3$ & $3 \cdot 8-22 \cdot 9$ \\
\hline By mol & $4 \cdot 8$ & 3.1 & $1 \cdot 3-10 \cdot 8$ & 4.8 & $2 \cdot 8$ & $2 \cdot 0-12 \cdot 2$ \\
\hline
\end{tabular}

${ }^{*}$ Mean value is significantly different between the two populations $(P<0.05)$. 

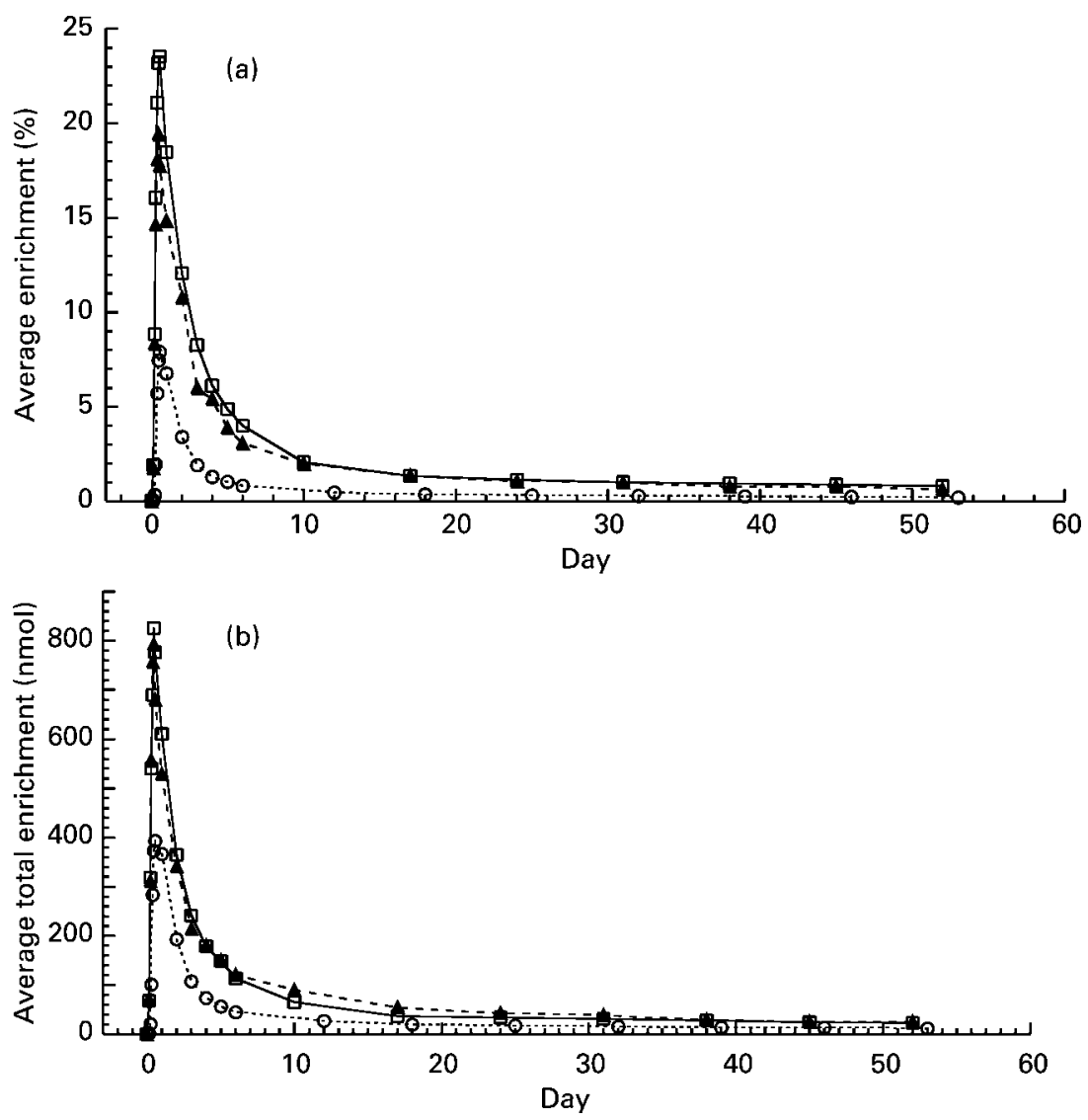

Fig. 4. Comparison of average serum $\left[{ }^{2} \mathrm{H}_{8}\right]$ retinol enrichment between the American volunteers (twenty-two subjects, twelve females and ten males; -o-) from the Tang et al. (2003) study and the Chinese volunteers of the present study. Fifteen Chinese farmer volunteers (nine males and six females) were studied after a $6 \mathrm{mg}$ dose of $\left[{ }^{2} \mathrm{H}_{8}\right] \beta$-carotene and a $\left[{ }^{2} \mathrm{H}_{8}\right]$ retinyl acetate reference dose using the same design as in the Tang et al. (2003) experiment. Among the fifteen subjects, eleven (seven males and four females) responded well to the $\left[{ }^{2} \mathrm{H}_{8}\right] \beta$-carotene dose (termed as normal converters; $-\square-$ ) and four (two males and two females) responded poorly to the $\left[{ }^{2} \mathrm{H}_{8}\right] \beta$-carotene dose (termed as poor converters; $-\mathbf{\Delta}-)$.

with the American subjects after the same $\left[{ }^{2} \mathrm{H}_{8}\right] \beta$-carotene dose and $\left[{ }^{2} \mathrm{H}_{8}\right] \mathrm{RAc}$ reference dose is uncertain, but it can be speculated that as the Chinese subjects had smaller vitamin A stores in the liver, the retinol converted from the $\left[{ }^{2} \mathrm{H}_{8}\right] \beta$-carotene dose or absorbed from the RAc dose was less diluted in the body pool and stayed in the circulation longer than in the American subjects. Similar observations in experiments on rats with high $v$. marginal vitamin A status were reported by Green et al. (1987). That is, the curves of plasma retinol kinetics in rats of marginal vitamin A status showed a higher AUC than that in rats of high vitamin A status. Thus, it is possible that the higher serum AUC responses are mainly due to the difference of body stores of vitamin A between the two populations.

Although it is believed, at present, that $50-70 \%$ of an oral dose of vitamin A will be absorbed, variability in the absorption of an oral vitamin $A$ dose is of concern when the conversion efficiency of $\beta$-carotene to vitamin A is being evaluated using an isotope dilution technique with retinol as the reference dose. This is because the derived conversion factors are relative to the ingested reference vitamin A dose response. As mentioned earlier, the higher AUC response of the Chinese subjects are mainly due to the lower body stores of vitamin A and, thus, might not imply the better absorption of vitamin A by the Chinese population. However, it is not clear if the absorption of vitamin A is different in the Chinese population from that in the US population.

The results of conversion factors in the present study are different from the conversion factors previously determined using a depletion-repletion study design to determine the $\beta$-carotene equivalence (conversion factor) to vitamin A. The reported $\beta$-carotene equivalence at the daily dose of $1200-1500 \mu \mathrm{g} \beta$-carotene from the depletion-repletion method usually ranges from $2 \cdot 0: 1$ to $3 \cdot 8: 1$ on a weight basis (Hume \& Krebs, 1949; Sauberlich et al. 1974). The major differences between the earlier studies and the present study are (1) the vitamin A status of the subjects being studied and (2) the amount of $\beta$-carotene dose. The higher conversion efficiencies of $\beta$-carotene to vitamin $A$ in earlier studies were obtained from experiments on vitamin A-depleted subjects $\nu$. the lower conversion efficiency seen in the better-nourished subjects in the present study. It was reported that the activity of intestinal $\beta$-carotene cleavage enzyme in vitamin A-sufficient rats is $50 \%$ of that in vitamin A-deficient rats (Villard \& Bates, 1986). Further, the doses of $\beta$-carotene used in these early studies $(1.2-1.5 \mathrm{mg} / \mathrm{d})$ were lower than the present study dose $(6 \mathrm{mg})$ and the conversion of $\beta$-carotene to vitamin $\mathrm{A}$ might be more efficient using a $1 \mathrm{mg}$ dose than a $6 \mathrm{mg}$ 
dose of $\beta$-carotene. However, based on the present experiment and that of Tang et al. (2003), the conversion factor of $6 \mathrm{mg} \beta$-carotene to vitamin A appears very similar in both Chinese and American study populations.

The intestine is the most important organ for the conversion of $\beta$-carotene to vitamin $A$, but other organs and tissues such as liver, fat, lung, and kidney are also capable of converting $\beta$-carotene to retinoids (Wang et al. 1991). In the present paper $24 \mathrm{~h}$ was used as the cut-off time to distinguish the intestinal conversion of $\beta$-carotene to retinol from the post-intestinal conversion of $\beta$-carotene to retinol (Tang et al. 2003). It was found that the post-intestinal conversion of vitamin A accounted for 19.7 to $30.1 \%$ of the total converted retinol over the period of 6 to $52 \mathrm{~d}$, respectively. The present results show that almost one-third of the total vitamin A formed from $6 \mathrm{mg}$ oral $\beta$-carotene was due to extra-intestinal (post-absorptive) cleavage in the Chinese adults. The present results differ from those from the study of Tang et al. (2003), in which it was reported that the average of $19 \%$ of total vitamin A formed from a $\beta$-carotene dose was from extra-intestinal cleavage in a well-nourished American population. It is possible that the percentage of post-intestinal conversion of $\beta$-carotene to retinol may also be related to a subject's vitamin A status.

The four poor converters in the present study showed strikingly poor responses to the labelled $\beta$-carotene dose. This indicates that the absorption and conversion of $\beta$-carotene is impaired in some human subjects, in whom dietary retinol can be absorbed normally. Lin et al. (2000), from the University of California, Davis, reported five poor responders in their experiment on eleven American women aged 19-39 years, in which they used crystalline $\beta$-carotene $(>15 \mu \mathrm{mol})$ and vitamin $A$ in gelatin capsules (not mixed in oil). However their poor responders also had much low absorption of vitamin A doses. The subjects in the present experiment deserve further study to explore the possible reasons (for example, genetic) for their low response to the labelled $\beta$-carotene and poor conversion of $\beta$-carotene to vitamin $\mathrm{A}$.

In summary, the conversion of $\beta$-carotene to vitamin $A$ in Chinese adults has been quantitatively determined by using a stable-isotope reference method. An average conversion factor of $9.1 \mu \mathrm{g} \beta$-carotene equivalent to $1 \mu \mathrm{g}$ retinol was found in eleven Chinese adults aged 50-60 years who were judged to be normal (or good) converters. The $52 \mathrm{~d}$ post-intestinal absorption conversion was estimated to account for $30 \%$ of the total converted retinol. Four volunteers were found to be poor converters, who responded very poorly to the labelled $\beta$-carotene dose but quite well to the labelled vitamin $A$ dose and exhibited $\beta$-carotene conversion efficiency to retinol as $>29: 1$ on a molar basis. Further investigations on possible genetic characteristics on $\beta$-carotene conversion to vitamin $\mathrm{A}$ in this population may provide a better understanding on the vitamin $\mathrm{A}$ value of $\beta$-carotene in man.

\section{Acknowledgements}

The authors thank the volunteer subjects and village doctors for participating in the study; J. Qin from the Carotenoids and Health Laboratory of the HNRCA
(Boston, MA, USA) and Q. M. Xu and J. Meng from the National Institute for Nutrition and Food Safety, Chinese Centre for Disease Control and Prevention, Beijing, for their help in sample analysis. The authors thank the nurses and dietitians, especially X. J. Yang, Hua Jiao, M. G. Cao and Y. L. Wang, from the town hospital and municipal hospital of Jining City, Shandong Province, China, for blood sampling and dietary guidance. The authors are grateful to BASF (Ludwigshafen, Germany) and the Carotenoids and Health Laboratory of the US Department of Agriculture HNRCA for providing the labelled $\beta$-carotene and RAc, respectively.

The present paper is based upon work supported by the Chinese National Natural Science Foundation grant no. 30271121 and the US Department of Agriculture, under agreement no. 581950-9-001. Any opinions, findings, conclusion, or recommendations expressed in this publication are those of the author(s) and do not necessarily reflect the view of the US Department of Agriculture.

\section{References}

Blomstrand R \& Werner B (1967) Studies on the intestinal absorption of radioactive $\beta$-carotene and vitamin $\mathrm{A}$ in man. Scand J Clin Lab Invest 19, 339-345.

Chinese Nutrition Society (2000) Chinese Dietary Reference Intakes, (In Chinese) pp. 264. Beijing, China: Light Industry Press.

Craft NE, Brown ED \& Smith JC (1988) Effects of storage and handling conditions on concentrations of individual carotenoids, retinol, and tocopherol in plasma. Clin Chem 34, 44-48.

Diem K (1962) Documenta Geigy: Scientific Tables, 6th ed., Ardsley, NY: Geigy Pharmaceuticals.

Food and Agriculture Organization/World Health Organization (1967) Requirements of vitamin A, thiamine, riboflavin, and niacin. Report of a Joint Food and Agriculture Organization/ World Health Organization Expert Committee, FAO Nutrition Meeting Report Series no. 41. WHO Technical Report Series no. 362 Geneva: WHO.

Furr HC, Amedee-Manesme O, Clifford AJ, et al. (1989) Vitamin A concentration in liver determined by isotope dilution assay with tetradeuterated vitamin A and biopsy in generally healthy humans. Am J Clin Nutr 49, 713-716.

Goodman DS, Blomstrand R, Werner B, Huang HS \& Shiratori (1966) The intestinal absorption and metabolism of vitamin $\mathrm{A}$ and $\beta$-carotene in man. J Clin Invest 45, 1615-1623.

Green MH, Green JB \& Lewis KC (1987) Variation in retinol utilization rate with vitamin A status in the rat. $J$ Nutr 117, 694-703.

Haskell M, Islam M, Handelman G, et al. (1998) Plasma kinetics of an oral dose of $\left[{ }^{2} \mathrm{H}_{4}\right]$ retinyl acetate in human subjects with estimated low or high total body stores of vitamin A. Am J Clin Nutr 68, 90-95.

Hume EM \& Krebs HA (1949) Vitamin A requirement of human adults. An experimental study of vitamin A deprivation in man. Medical Research Council Special Report Series no. 264. London: His Majesty's Stationery Office.

Institute of Nutrition and Food Hygiene, Chinese Academy of Preventive Medicine (1996) The Dietary and Nutritional Status of Chinese Population (1992 National Nutrition Survey), [KY Ge, editor]. (In Chinese)pp. 195. Beijing, China: People's Medical Publishing House.

Johnson EJ, Hammond BR, Yeum KJ, et al. (2000) Relation 
among serum and tissue concentrations of lutein and zeaxanthin and macular pigment density. Am J Clin Nutr 71, 1555-1562.

Lin Y, Dueker SR, Burri BJ, et al. (2000) Variability of the conversion of $\beta$-carotene to vitamin $A$ in women measured by using a double-tracer study design. Am J Clin Nutr 71, $1545-1554$.

National Research Council (1989) Recommended Dietary Allowances, 10th ed., Washington, DC: National Academy Press.

Olson JA (1986) Carotenoids, vitamin A and cancer. J Nutr 116, 1127-1130.

Ribaya-Mercado JD, Solon FS, Cabal-Barza MA, et al. (2000) Bioconversion of plant carotenoids to vitamin A in Filipino school-aged children varies inversely with vitamin A status. Am J Clin Nutr 72, 455-465.

Rothman KJ, Moore LL, Singer MR, et al. (1995) Teratogenicity of high vitamin A intake. N Engl J Med 333, 1369-1373.

Sauberlich HE, Hodges RE, Wallace DL, et al. (1974) Vitamin A metabolism and requirements in the human studied with the use of labelled retinol. Vitam Horm 32, 251-275.

Solomons NW (2001) Vitamin A and carotenoids. In Present Knowledge in Nutrition, 8th ed., pp. 127-139 [BA Bowman and RM Russell, editors]. Washington, DC: ILSI Press.

Tang G, Andrien BA Jr, Dolnikowski GG \& Russell RM (1997) Atmospheric pressure chemical ionization and electron capture negative chemical ionization mass spectrometry in studying $\beta$-carotene conversion to retinol in humans. Meth Enzymol 282, 140-154.

Tang G, Donikowski GG, Blanco MC, et al. (1993) Serum carotenoids and retinoids in ferrets fed canthaxanthin. $J$ Nutr Biochem 4, 58-63.

Tang G, Qin J \& Dolnikowskl GG (1998) Deuterium enrichment of retinol in humans determined by gas chromatography electron capture negative chemical ionization mass spectrometry. $J$ Nutr Biochem 9, 408-414.

Tang G, Qin J, Dolnikowski GG \& Russell RM (2000) Vitamin A equivalence of $\beta$-carotene in a woman as determined by a stable isotope reference method. Eur J Nutr 39, 7-11.

Tang G, Qin J, Dolnikowski GG \& Russell RM (2003) Short-term (intestinal) and long-term (whole-body) conversion of $\beta$-carotene to vitamin A in adults using a stable isotope reference method. Am J Clin Nutr 78, 259-266.

Tang G, Qin J, Hao L, Yin S \& Russell RM (2002) Use of a shortterm isotope-dilution method for determining the vitamin A status of children. Am J Clin Nutr 76, 413-418.

US Institute of Medicine (2001) Dietary reference intakes for vitamin $\mathrm{A}$, vitamin $\mathrm{K}$, arsenic, boron, chromium, copper, iodine, iron, manganese, molybdenum, nickel, silicon, vanadium, and zinc. A Report of the Panel on Micronutrients, Subcommittees on Upper Reference Levels of Nutrients and of Interpretation and Use of Dietary Reference Intakes, and the Standing Committee on the Scientific Evaluation of Dietary Reference Intakes. Food and Nutrition Board, Institute of Medicine. Washington, DC: National Academy Press.

Villard L \& Bates C (1986) Carotene dioxygenase [EC 1.13.11.21] activity in rat intestine: effects of vitamin A deficiency and pregnancy. Br J Nutr 56, 115-122.

Wang X, Tang G, Fox J, et al. (1991) Enzymatic conversion of $\beta$ carotene into $\beta$-apo-carotenals and retinoids by human, monkey, ferret, and rat tissues. Arch Biochem Biophys 285, $8-16$.

World Health Organization (1995) Global Prevalence of Vitamin A Deficiency, (WHO/NUT/95.3). Geneva: WHO.

Yeum KJ, Booth SL, Sadowski JA, et al. (1996) Human plasma carotenoid response to the ingestion of controlled diets high in fruits and vegetables. Am J Clin Nutr 64, 594-602. 